Выводы. Анализ данных показал, что разработанное сверло обеспечивает более низкую шероховатость поверхностей отверстий, чем сверло SECO при одинаковой величине износа главных режущих кромок. Такой результат, главным образом, обусловлен работой вспомогательных режущих кромок разработанного сверла на реверсивном ходу.

Ключевые слова: сверление, акустическая эмиссия, углепластик.

${ }^{1)}$ A. I. Hrechuk, ${ }^{2)}$ A. V. Globa, ${ }^{1)}$ L. M. Devin

${ }^{1)} \mathrm{V}$. Bakul Institute of Superhard materials, Kyiv, Ukraine

${ }^{2)}$ National Technical University of Ukraine "Igor Sikorsky Kyiv Polytechnic Institute", Kyiv, Ukraine

\title{
INCREASING THE QUALITY OF DRILLING HOLES IN FIBER REINFORCEMENT COMPOSITE MATERIALS
}

Problems. Fiber reinforcement polymer composite materials (FRP) are used in many areas of modern machine building, mostly in aircraft and aerospace industries. Millions of high-quality holes in FRP details are necessary for production of a modern passenger aircraft, to provide reliable bolt and rivet connections. Drilling is a key-machining operation for the production of holes in FRP.

Comparing metal-containing materials drilling, FRP drilling is accompanied by the appearance of specific defects, such as delamination, uncut fibers, the damages of FRP's matrix from the holes surface and thermal destruction. The listed defects adversely affect the reliability of bolt and rivet joints between parts of FRP, which determines the relevance of this study.

The aim of the study. Determination of the influence of the support cutting edges of the developed drill with superhard materials on the holes surfaces quality of carbon fiber reinforcement plastics (CFRP) samples.

Research methodology. The goals were achieved by experimental investigations on drilling CFRP samples by the designed drill bits and drill bit from SECO (Sweden) with similar cutting conditions. The drilling process was accompanied by the registration the axial force of cutting, torque and the acoustic emission signal. The analysis of the registered signals allowed to study the features of support cutting edges of the developed drill. The quality of the drilled holes surfaces was analyzed by determining the roughness using Alicona Infinite Focus (Austria) optical microscope. Conclusions were made according to the results of experimental studies.

Conclusions. Analyzed data are shown, that the developed drill provides twice the lower roughness of the holes surfaces than the drill SECO, according to the same level of the wear of the main cutting edges. These results are mainly due to the work of the support cutting edges of the developed drill on a reversing feed.

Keywords: drilling, acoustic emission, CFRP.

Надійшла до редакиії 08 листопада 2017 року

Рецензовано

18 листопада 2017 року

(C) Гречук А. І., Глоба О. В., Девін Л. М., 2017

\section{УДК 536.212:536.627 \\ МЕТОД КОНТРОЛЮ СТУПЕНЯ СФЕРОЇДИЗАЦІЇ ГРАФІТУ У ВИСОКОМІЦОМУ ЧАВУНІ}

\author{
Шевченко О. I. \\ Головна астрономічна обсерваторія НАН Украӥни, м. Київ, Україна \\ E-mail: $\underline{\text { soi_51@ukr.net }}$
}

У статті наведено аналіз наявних методів, стандартних зразків, засобів вимірювальної техніки (3BT) та державних стандартів і моделей вимірювань при розробленні та виготовленні виробів з чавуну. Основу технологї ливарного виробництва становлять теплові процеси. Значна частина усіх вимірювань, щзо виконуються у цехових та лабораторних умовах, припадає на теплофізичні вимірювання. Наявні теплофізичні методи контролю мають недостатньо високу чутливість та роздільну здатність у визначенні технологічних параметрів. Описаний перетворювач та метод вимірювання ступеня сфероїдизачії графіту у високоміцному чавуні у промислових умовах на автомобільному заводі.

Показано зв'язок між структурою графіту у чавуні, коефіиієнтом теплопровідності та вимірювальним сигналом. Відмічено вплив металевої матриці на результати вимірювання. Наведена 
конструкція вимірювального перетворювача; результати та похибки вимірювання, приклади деталей вантажного автомобіля, які було проконтрольовано.

Ключові слова: високоміџний чавун, перетворювач, метод контролю, коефіцієнт теплопровідності чавунів.

\section{Ветуп}

Для машинобудування суттєве значення має якість продукції 3 чавуну. Під наукоємними технологіями машинобудування розуміють розробку та впровадження у виробництво таких нових виробів машинобудування, які потребують багаторічних досліджень у наукових академічних інститутах, галузевих науково-дослідних інститутах та у центральних заводських лабораторіях. Наукоємні технології у машинобудуванні розробляються разом 3 методами та приладами для вимірювання фізичних властивостей матеріалів. Разом 3 тим, метрологічне забезпечення (МЗ) вимірювань механічних та теплофізичних характеристик (ТФХ) чавунів і випробувань продукції з чавуну в Україні розвинуте недостатньо. Технічні характеристики виробів 3 чавуну визначаються шляхом механічних випробувань на розривних машинах, акустико-емісійних та теплофізичних вимірювань, ультразвукової дефектоскопії, люмінесцентними та магнітними методами. На сьогодні необхідні модифікації та удосконалення цих методів, а також розроблення нових методів.

Основу технології ливарного виробництва становлять теплові процеси. Значна частина усіх вимірювань, що виконуються у цехових та лабораторних умовах, припадає на теплофізичні вимірювання. Наявні теплофізичні методи контролю мають недостатньо високу чутливість та роздільну здатність у визначенні технологічних параметрів. Нижче наведено низку прикладів, які показують зв'язок i вплив теплофізичних характеристик на якісні показники металів. При дослідженні ТФХ високоміцних чавунів (ВмЧ) 3 різною формою графіту, порогова чутливість визначення коефіцієнту теплопровідності повинна бути не меншою 3,6 \%, що відповідає 5 Вт/(м·К). Для визначення ступеня феритизації чавуну, що йде на виготовлення відповідальних деталей, наприклад циліндрів високого тиску, порогова чутливість визначення питомої теплоємності у виробничих умовах повинна бути не меншою $1,8 \%$.

Якісно нові вимоги до рівня сучасної вимірювальної техніки ставлять завдання впровадження методів, які дозволяють підвищити чутливість і точність контролю.

Прилади для визначення ТФХ на Україні не виготовляються. Державні, вторинні, вихідні еталони та засоби вимірювальної техніки (ЗВТ) для визначення теплофізичних характеристик у діапазоні до $600{ }^{\circ} \mathrm{C}$ відсутні. Вітчизняних теплофізичних методів та приладів для технологічного, неруйнівного контролю та дослідницьких вимірювань в Україні недостатньо.
Сдиний прилад, що випускався раніше і добре себе зарекомендував, це «Измеритель теплофизических свойств ИТС-400» (Платунов Е. С.). Визначення параметрів кристалічної решітки цих чавунів відбувається за допомогою оптичних мікроскопів. Більшість стандартів на виготовлення сучасних марок чавунів і методів їх контролю прийнято понад 30 років тому.

М3 включає забезпечення виробництва ЗВТ та можливість повірки та калібрування ЗВТ. Але не менш важливим для МЗ $є$ наявність стандартних зразків складу i властивостей матеріалів та стандартних довідкових даних (СДД). Ця робота в останні роки практично припинена.

Постановка завдання. Аналіз наявних методів, стандартних зразків, засобів вимірювальної техніки та моделей вимірювань при розробленні та виготовленні виробів 3 чавуну

Нижче наводиться одна 3 причин затримки створення стандартних зразків (С3). Вважається, що оскільки технологічний контроль прямо не належить до державного метрологічного нагляду, то і нема потреби атестовувати державні C3 на підприємствах під час технологічного контролю. Але такий підхід призводить до того, що коли випробовуються вироби з цих матеріалів під час сертифікації машин, обладнання та устаткування, ці вироби відносять до небезпечних, тобто таких, що підпадають під сферу державного метрологічного нагляду (ДМН), і виявляється, що атестувати C3 нема на чому. Наприклад, до Державного реєстру засобів вимірювальної техніки в Україні занесений лише один комплект ДСЗУ 083.26-2009 складу чавуну ливарного, переробного та легованого СН01-CH08 (комплект для спектрального аналізу). У Міждержавному реєстрі міждержавних стандартних зразків наявні для прикладу такі С3 (табл. 1).

Відсутні СДД властивостей чавунів. При цьому, саме питання атестації С3 проблематичне, оскільки немає методик атестації. Складнощі виникають під час робіт 3 діагностування i моніторингу надійності та довговічності виробів. Можна перерахувати деякі відомі високотехнологічні об'єкти: силові металоконструкції (стріли вантажопіднімальних машин), механізми та машинне обладнання (насоси, компресори), трубопроводи, парогенератори та ін. Несправності та дефекти у цих системах призводять до небажаних та небезпечних наслідків. Існують стандарти щодо метрологічного забезпечення контролю стану складних технічних систем. 
Таблиця 1. Міждержавні стандартні зразки чавуну

\begin{tabular}{|c|l|l|l|}
\hline $\begin{array}{c}\text { № } \\
\text { 3/п }\end{array}$ & $\begin{array}{c}\text { Ресстраційний } \\
\text { номер }\end{array}$ & \multicolumn{1}{|c|}{ Найменування МС3 } & \multicolumn{1}{|c|}{$\begin{array}{c}\text { Номер С3 за } \\
\text { національним ресстром }\end{array}$} \\
\hline 1 & МСО 0117:1999 & С3 складу чавуну ливарного типу Л6 (Ч4) & ГСО 1690-93П \\
\hline 2 & МСО 0219:2001 & $\begin{array}{l}\text { С3 складу чавуну легованого типу ЧХЗТ } \\
\text { (Ч15) }\end{array}$ & ГСО 8020-94 \\
\hline 3 & МСО 0237:2001 & $\begin{array}{l}\text { С3 складу чавуну передільного типів ПФ1, } \\
\text { ПФ3, П2, ПВК3 (комплект СО ЧГ1 - ЧГ6) }\end{array}$ & ГСО 2482-92П - 2487-93П \\
\hline
\end{tabular}

У них підкреслюється необхідність мати С3 та СДД. Звичайно, якщо під час виробництва ці СЗ та СДД не було створено, то під час експлуатації немає можливості забезпечити виконання стандартів. В зазначених умовах і відсутні міри, і зміни метрологічних характеристик виходять за допустимі межі і кількість проведених вимірювань обмежена та $€$ непрогнозованою.

Вироби 3 чавуну. Для виготовлення прогресивних марок чавуну існують стандарти ДСТУ 3925 [1] та ГОСТ 7293 [2]. Чавун з кулястим графітом (ЧКГ) $є$ перспективним при використанні в атомній енергетиці, фірма «Симпалкам» (Німеччина) виливає з феритного ЧКГ контейнери типу «Кастор» масою 85 т для збереження відпрацьованих ядерно-паливних стрижнів.

Для чавуну 3 кулястим графітом (рос. шаровидным) існують такі вимоги: підвищена корозійна стійкість у газовому, повітряному та лужному середовищах і умовах тертя та зносу; жаростійкість у повітряному середовищі; стійкість проти абразивного зносу (особливо проти ударноабразивного зносу та стирання); стійкість до дії неорганічних кислот великої концентрації та ін.

Звісно, що вимоги до чавуну у стандарті ДСТУ 3925 [1], а саме: тимчасовий опір розриву під час розтягування $\sigma_{в}$, відносне видовження $\delta$, структура графіту в чавуні, умовна границя плинності $\delta_{0,2}$, твердість за Брінелем, не мають прямого відношення до зазначених експлуатаційних характеристик. Не всі необхідні вимоги до виробів зазначаються у стандартах.

Для постачання на експорт сертифікаційні випробування продукції не будуть забезпечені приладами, методами та методиками вимірювань. Аналогічна ситуація з ГОСТ 7293 [2]. Наведених в стандарті вимог до технічних характеристик недостатньо для забезпечення експлуатаційних характеристик: деталей загального машинобудування, що працюють при підвищених циклічних механічних навантаженнях, при змінних підвищених температурах.

Загальним недоліком МЗ незалежно цього виду вимірювань $\epsilon$ недостатня кількість сучасних вимірювальних перетворювачів у складі приладів, що забезпечують підвищену точність та роздільну здатність вимірювань.

Відповідно відсутні ЗВТ, повірочні схеми, С3, СДД. За останні роки рівень наукових досліджень із створення сучасних ЗВТ для контролю сучасної продукції вітчизняного машинобудування, на жаль, знизився. Процедури підготовки С3 підприємств характеризуються недосконалістю, відривом від реальних технологій, що існують на виробництві. Кількість вимог до якісних параметрів виробів у процесі виробництва набагато менші, ніж вимоги до параметрів під час їх експлуатації. Тобто кількість метрологічних характеристик методів вимірювань фізичних властивостей менша ніж кількість експлуатаційних характеристик виробів. При цьому, вони слабо корелюють між собою.

Після 90-х років виробництво ЗВТ для контролю продукції машинобудування залишилось поза межами України або припинило своє існування. Впровадження міжнародних стандартів виявило певні проблеми у проведенні сертифікації металопродукції машинобудування. Історично склалося, що високий науковий потенціал був переважно залучений під час розробки виробів зі сталі. Що стосується виробів з чавуну, то досліджень його теплофізичних та механічних властивостей проведено менше. Інтерес до виробів 3 чавуну збільшився зі створенням марок високоміцного чавуну з кулястим графітом (ЧКГ) та вермикулярним графітом (ЧВГ). Збільшилися вимоги до технології лиття, параметрів модифікаторів та механічних властивостей. Однак М3 вимірювальних та випробувальних лабораторій $з$ контролю продукції 3 чавунів в Україні залишається на низькому рівні.

На вимірювання ТФХ є декілька стандартів: на вимірювання теплопровідності, але переважно низької, до $20 \mathrm{Bт} /(\mathrm{м} \cdot К)$ (ДСТУ ГОСТ 8.140 [3] та ДСТУ ГОСТ 8.141) [4], та на вимірювання теплоємності.

Відомі декілька способів визначення ТФХ, наприклад: «Способ определения теплопроводности материалов» (Патент RU № 233466) [5].

Недоліком вказаних способів $\epsilon$ невелика точність вимірювання температури термоперетворювачем, який розташований під ізоляційним кільцем через різні контактні термічні опори матеріалу.

3 роками під час експлуатації надійність виробів зменшується. Питання МЗ технологічного та неруйнівного контролю в умовах виробництва залишається актуальним до цього часу. Інформація щодо ТФХ чавунів наявна у роботах [6-11]. чавуну

Мета роботи. Теплові методи контролю Протягом останнього десятиріччя у машинобудуванні, зокрема в автомобільній промисловості, 
впроваджуються відливки з високоміцного чавуну. Ці відливки використовуються у вузлах, які піддаються великим механічним навантаженням. $€$ багато чинників, що впливають на якість високоміцного чавуну: процеси виплавки, температура модифікування, вміст газів, хімічний склад металу. Впливають також і організаційні питання, наприклад, помилкове використання іншої лігатури. Різноманітність факторів, що впливають на отримання високоміцного чавуну, не дає можливості в умовах ливарного виробництва отримати 100 \% гарантію якості лиття. Такі великі відливки 3 високоміцного чавуну, як маточини коліс, картер редуктора заднього мосту, необхідно контролювати перед відправленням на оброблювальний завод. Часто буває, що брак ллється протягом 2-3 днів. Відомості щодо браку надходять із затримкою і втрачається інформація, яка партія продукції є бракованою. У результаті, у цехах накопичується вся продукція зазначених днів виробництва, включаючи й якісну. Тому існує економічна доцільність контролю якості продукції в умовах конвеєрного виробництва.

На сьогодні існує декілька методів контролю форми графіту у чавуні: звуковий - через модуль пружності і щільність чавуну; ультразвуковий - на основі аналізу швидкостей ультразвуку; за допомогою термографічного аналізу (ТА) - за термограмами охолодження; за електричним опором проби чавуну, який твердне. Відомий метод металографічного аналізу, коли з деталі вирізається проба, шліфується, полірується та досліджується

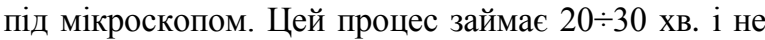
підходить для аналізу чавуну в умовах конвеєру. При цьому аналізується лише шар металу товщиною декілька мкм. У той же час необхідно визначати інтегральні характеристики структури графіту товщиною до $2 \div 3$ мм. Візуальний метод $є$ напівкількісним, оскільки деякі включення графіту можуть бути у глибині пов'язані одне з одним, а на поверхні виглядати як різні частинки. Одночасно 3 визначенням форми графіту у відливках визначали по клиновій пробі відтінок макрозлому: світло сталевий - для ЧКГ, матово-чорний - для СЧ i сірувато-матовий із сталево-точковими вкрапленнями - для ЧВГ, що відповідно до статистичних даних по шкалі Фізикотехнологічного інституту металів i сплавів (ФТІМС) Національної академії наук України (НАНУ) відповідає значенню від $(50 \div 60) \%(Г ф 5$,

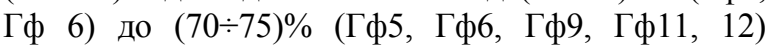
ступені сфероїдизації графіту (ССГ). Одночасно на цьому клину визначають величину відбілу чавуну (у мм по товщині клину), яка також характеризує ефект модифікування при заданому вмісті вуглецю і кремнію у чавуні. Поряд 3 пробою на макрозлом $\mathrm{i}$ відбіл періодично заливалася у кокіль тонкостінна пластинка для визначення хімічного складу чавуну i заливався великий клин для визначення механічних властивостей.

\section{Характеристики чавунів}

У роботі [7] проведено аналіз впливу складових чавуну на його ТФХ. «Питома теплоємність чистого заліза більша ніж сірого чавуну, а білого більша ніж заліза. Пояснюється це наявністю карбіду заліза 3 більш високою теплоємністю» [8].

«Графітизація зменшує теплоємність металу» [7]. «Інші зміни у структурі чавуну, крім графітизації (наприклад будова перліту або форма виділення графіту), практично на теплоємність не впливають. Теплоємність також мало залежить від металу» [7]. «Підвищення вмісту вуглецю в ЧПГ збільшує теплопровідність, якщо у структурі збільшується кількість графіту; збільшення зв'язаного вуглецю у металевій основі знижує теплопровідність чавуну». «Сфероїдизація графіту значно знижує теплопровідність чавуну. У феритному ЧКГ зміна вмісту вуглецю практично не впливає на теплопровідність» [7]. Аналіз наведених літературних даних дав можливість автору виявити, що в умовах виробництва чавуну 3 вермикулярним та кулевидним графітом (що виробляється за технологіями відповідно до чинних стандартів) найбільше відхилення у показниках якості та марці чавуну залежить саме від форми графіту, а не від структурних складових (ферит, цементіт, перлит) та хімічного складу чавуну. Інші методи мають такі недоліки: визначення видовження під час тверднення не забезпечує достатньої точності; визначення поверхневого натягу рідкого металу важко реалізувати в умовах цеху. Аналіз точності різних методів контролю показав, що тепловий метод контролю не поступається ультразвуковому.

На рис. 1 показано вигляд двох важливих деталей вантажних автомобілів КАМАЗ, які виготовляються 3 високоміцного чавуну. Крім цих деталей контролювалися: маточина переднього колеса з ВЧ50 (марка виробу, 5320-3103015); башмак ресори, картер рульового управління, блок циліндрів та ін.

У роботі [9] проведено аналіз впливу складових чавуну на ТФХ. У роботі [7] наводиться формула залежності теплопровідності $\lambda$ у ЧВГ від відносної кількості кулястого графіту: $\lambda=34,1+$ $0,094 \cdot x$, де $x$ - відносна кількість КГ (у межах $0 \%$ -100 \%). У роботі [7] наведені дані щодо лінійної пропорційної залежності температуропровідності від усередненого коефіцієнта форми графіту для температур $(25,400,800){ }^{\circ} \mathrm{C}$ для ЧКГ, ЧВГ, ЧПГ. У чавуні з кулястим графітом при збільшенні ССГ $\%$ відносне видовження $\delta$ збільшується від $2 \%$ до $15 \%$ для феритного чавуна, ударна в'язкість $\mathrm{a}_{\text {н }}$ збільшується $32 \%$ до $8 \%$, межа міцності при

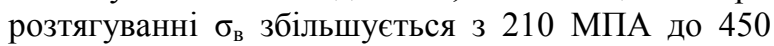
МПа, межа текучості $\sigma_{0,2}$ збільшують з 210 МПА до 320 МПА. Ці параметри корелюють із ССГ \%, яка у свою чергу лінійно пов'язана із теплопровідністю. 


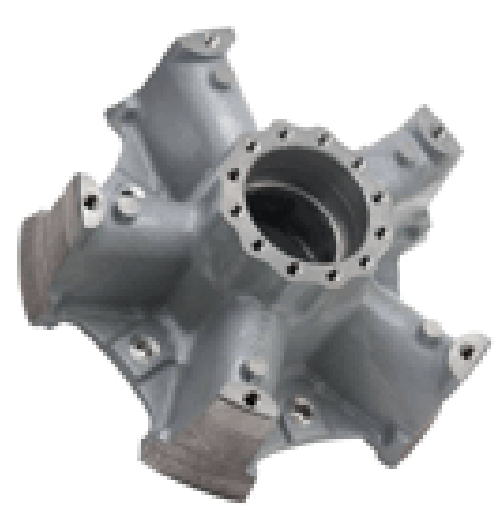

a) $65115-3104010$

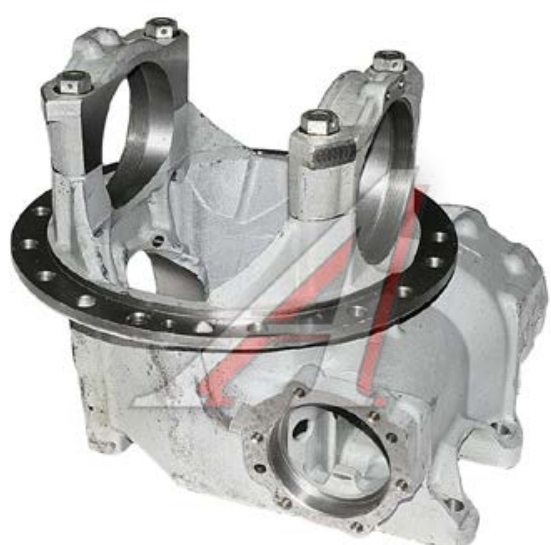

б) 5320-52402015

Рис. 1. Вигляд маточини заднього колеса - a); та картера редуктора заднього моста вантажного автомобіля - б) чавунів

Метод вимірювання ступеня сфероїдизації

На рис. 2, 3 наведено конструкцію датчика (перетворювача). Використано теплову модель ізотермічного калориметра. Для контролю деталі 3 високоміцного (або вермикулярного чавуну) на поверхні деталі зачищається плоска поверхня. Після змазування цієї поверхні машинною оливою, до неї прикладається торець перетворювача (рис. 2).

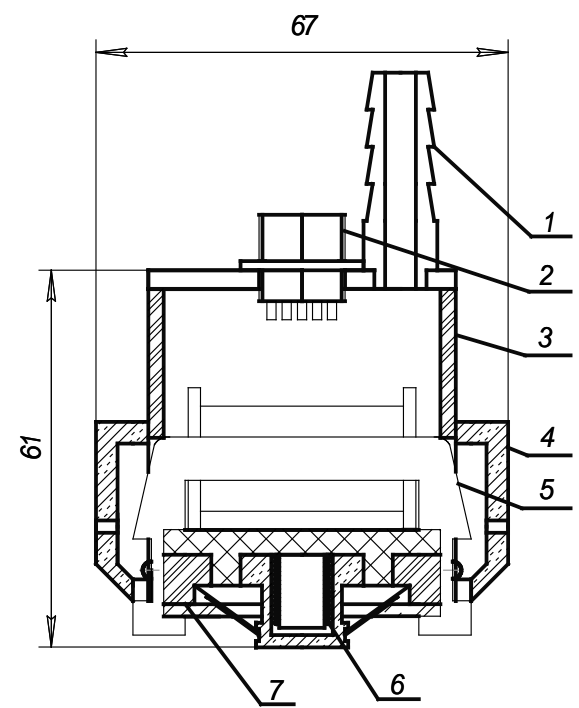

Рис. 2. Конструкція датчика, де: 1 - штуцер вводу повітря; 2 - електричний роз'єм; 3 - корпус датчика; 4 - корпус охолоджувача датчика; 5 - електромагніт; 6 - нагрівач (гарячі спаї термоперетворювача); 7 - термостат (холодні спаї термоперетворювача)

Температура нагрівання торця перетворювача підтримується на рівні $100{ }^{\circ} \mathrm{C}$. У вимірювальному блоці інтегрується площа під сигналом охолодження перетворювача. Перетворювач становить собою батарею 3 близько $n=100$ диференційних мідь-константанових термопар. Для перетворювача основним шумом є флуктуація температур навколишнього середовища. Дисперсія випадкових величин (теплових шумів) всього перетворювача дорівнює де $\mathbf{D} x_{i},-$ дисперсія окремої термопари.

$$
\mathbf{D}\left[\sum_{\mathrm{i}=1}^{\mathrm{n}} \mathrm{x}_{\mathrm{i}}\right]=\sum_{\mathrm{i}=1}^{\mathrm{n}} \mathrm{D} \mathrm{x}_{\mathrm{i}}=n \mathbf{D} x,
$$

де $\mathbf{D} x$ - дисперсія однакових термопар.

$$
\mathbf{D} X=\mathbf{D}\left(n \cdot x_{i}\right)
$$

Середнє квадратичне відхилення випадкової величини для окремої термопари дорівнює $\sigma_{X i}=\sqrt{D x_{i}}$, а для всього перетворювача: $\sigma_{X}=\sqrt{n D x}$.

У табл. 2 наведено літературні дані щодо хімічного складу та теплопровідності різних марок чавуну.

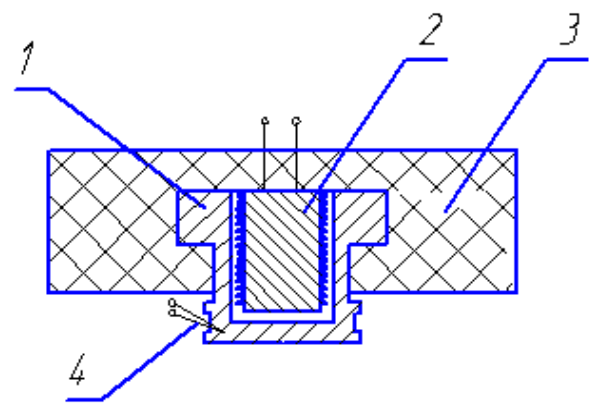

Рис. 3. Чутливий елемент пристрій для контролю теплопровідності, де: 1 - мідна втулка (датчик), 2 - нагрівач, 3 - ебонітовий корпус, 4 - термопара мідь-константан

Максимальну теплопровідність між пластинчатими чавунами має перлитний чавун.

Відповідно до чинних стандартів контролюються наступні параметри: форма графіту (структура);

межа міцності при розтяганні $\sigma_{\mathrm{B}}$ : ССГ $=(98 \div 55) \% ; \sigma_{\mathrm{B}}=(470 \div 230) \mathrm{MПа} \mathrm{(ферит);}$ $\sigma_{\mathrm{B}}=(630 \div 360) \mathrm{MПа} \mathrm{(перлит);}$ 
модуль пружності $E$ : для ССГ = $(55 \div 70) \%, E=$ $(137 \times 103 \div 155 \times 103)$ МПа;

межа міцності $\sigma_{\mathrm{B}}$ : для ССГ $=(55 \div 98) \%$;
$\sigma_{\mathrm{B}}=(521 \div 972)$ МПа.

Візуально на оптичному мікроскопі порівнянням 3 атласами форм графіту.

Таблиця 2. Вплив складу, структури і форми графіту на теплопровідність чавунів [7-13]

\begin{tabular}{|c|c|c|c|c|c|c|c|c|c|}
\hline \multirow[t]{2}{*}{ Матеріал } & \multicolumn{7}{|c|}{ Хімічний склад } & \multirow{2}{*}{$\begin{array}{l}\text { Середня темпе- } \\
\text { ратура, }{ }^{\circ} \mathrm{C}\end{array}$} & \multirow{2}{*}{$\begin{array}{l}\text { Теплопро- } \\
\text { відність, } \\
\text { Вт/(м•К) }\end{array}$} \\
\hline & $\mathrm{C}_{\text {заг }}$ & $\mathrm{Si}$ & $\mathrm{Mn}$ & $\mathrm{S}$ & $\mathrm{P}$ & $\mathrm{Ni}$ & $\mathrm{Mg}$ & & \\
\hline Чисте залізо & - & - & - & - & - & - & - & 100 & 69 \\
\hline \multirow[t]{3}{*}{ Сталь } & 0,23 & - & - & - & - & - & - & 100 & 51 \\
\hline & 0,40 & - & - & - & - & - & - & 100 & 48 \\
\hline & 1,20 & - & - & - & - & - & - & 100 & 45 \\
\hline \multicolumn{10}{|l|}{ ЧПГ } \\
\hline $\begin{array}{l}\text { Звичайний } \\
\text { сірий }\end{array}$ & 3,18 & 2,08 & 0,60 & 0,112 & 0,097 & - & - & 100 & 49 \\
\hline Відпалений & 3,18 & 2,08 & 0,60 & 0,112 & 0,097 & - & - & 100 & 53 \\
\hline $\begin{array}{l}\text { Низькокре- } \\
\text { м'янистий }\end{array}$ & 3,35 & 0,65 & - & - & - & - & - & 90 & 57 \\
\hline Перлитний & 3,09 & 0,55 & 1,09 & 0,103 & 0,180 & - & - & 100 & 65 \\
\hline \multicolumn{10}{|l|}{ ЧКГ } \\
\hline Перлитний & 3,22 & 2,44 & - & - & - & 1,35 & 0,056 & 100 & 31 \\
\hline Феритний & 3,52 & 2,05 & - & - & - & 0,05 & 0,066 & 100 & 39 \\
\hline Аустенітний & 2,95 & 1,85 & - & - & - & 20,70 & 0,120 & 100 & 19 \\
\hline
\end{tabular}

\section{Результати вимірювань}

Одночасно з визначенням форми графіту у відливках визначали по клиновій пробі відтінок макрозлому: світло сталевий - для ЧКГ, матовочорний - для СЧ і сірувато-матовий із сталевоточковими вкрапленнями - для ЧВГ, що відповідно до статистичних даних по шкалі ФТІМС НАН України відповідає Фізикотехнологічного інституту металів і сплавів

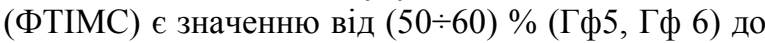

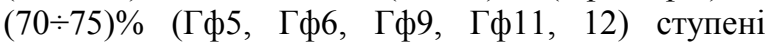
сфероїдизації графіту (ССГ). Одночасно на цьому клину визначають величину відбілу чавуну (у міліметрах по товщині клину), яка також характеризує ефект модифікування при заданому вмісті вуглецю і кремнію у чавуні.

Поряд 3 пробою на макрозлом i відбіл періодично заливалася у кокіль тонкостінна пластинка для визначення хімічного складу чавуну i заливався великий клин для визначення механічних властивостей. Оцінка форми графіту у більшості національних стандартів, у тому числі ИСО 945, відбувається за С3, які не дають кількісної оцінки. Тільки у стандарті Японії JIS G 5502 наведена формула розрахунку ССГ (\%).

Технічні дані приладу: діапазон контролю коефіцієнта теплопровідності $\lambda$, $(30 \div 55) \mathrm{BT} /(\mathrm{M} \cdot \mathrm{K})$; час вимірювань, с, не більш - 5; діапазон зміни температур зразка до вимірювання, ${ }^{\circ} \mathrm{C}, 20 \div 40$; постійна часу, с, не більше - 0,2; тиск

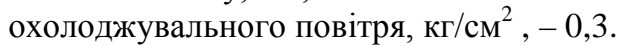

Порівняння 3 аналогом за інформацією у проспекті фірми «Вітасонік», Великобританія (прилад «Мат- а-Чек»). При 100 \% вмісті фериту і

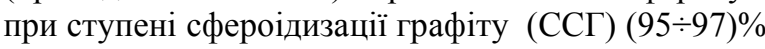
поздовжня швидкість $c_{l}$ УЗ становила $5600 \mathrm{~m} / \mathrm{c}$, для ССГ $20 \%$ - відповідно 5150 м/с. Різниця у швидкості УЗ становить лише 8\%. Коефіцієнт теплопровідності для цих чавунів дорівнює відповідно 40 і 50, тобто різниця у коефіцієнті теплопровідності становить $20 \%$.

Відомі роботи Захарченка Е. В. [7], у яких наводиться формула залежності теплопровідності у ЧВГ від відносної кількості кулястого графіту $\mathrm{C} \Gamma$ :

$$
\lambda=34,1+0,094 \cdot x,
$$

де $x$ - відносна кількість кулевидного графіту (у межах $(0 \div 100) \%$.

У чавуні з КГ при збільшенні ступеня сфероїдизації графіту (ССГ) \% відносне видовження $\delta$ збільшується від 2 до $15 \%$ для феритного чавуну, ударна в'язкість $\mathrm{a}_{\mathrm{H}}$ збільшується 32 до 8\%; межа міцності при

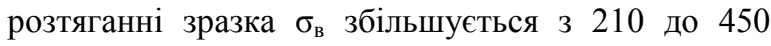
МПа; межа текучості $\sigma_{0,2}$ збільшується з 210 до 320 МПА. Ці параметри корелюють з ССГ \%, яка, у свою чергу, лінійно пов'язана 3 теплопровідністю. При значенні ССГ більше 70 \% в структурі чавуну переважає графіт кулевидноїі форми. Оцінка форми графіту у більшості національних стандартів, у тому числі ИСО 945, (ГОСТ 3443 [12]) відбувається за С3, які не дають кількісної оцінки. Тільки у стандарті Японії JIS G 5502-2000 Spheroidal graphite iron castings, наведена формула розрахунку ССГ (\%).

Для завдань кількісного металографічного аналізу використовується двовимірний фактор форми $\Phi$, який визначається величиною відношення периметра кола $\mathrm{P}$, що $\epsilon$ рівновеликою площі фігури, до периметру цієї фігури. Фактор форми $\Phi$ вказує, яка частка периметру фігури $P$ охоплює рівновелике до неї коло (Салтыков С. А. 
[13]) На рис. 4 показана шкала для оцінки графітових включень у чавуні за фактором форми $\Phi$,

$$
\Phi=2 \frac{\sqrt{\pi \mathrm{F}}}{\mathrm{P}}=3,545 \frac{\sqrt{\mathrm{F}}}{\mathrm{P}},
$$

де $F$ - форма включень графіту.

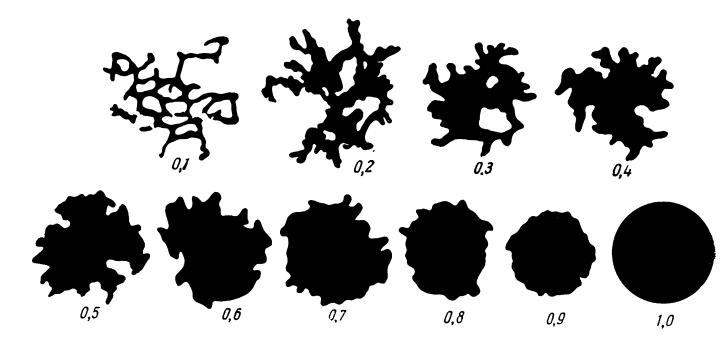

Рис. 4. Шкала для оцінки графітових включень у чавуні за фактором форми $\Phi$ (Салтыков С. А. [13])

На основі цього фактора побудована шкала для оцінювання форми графітових включень у чавуні. Оскільки включення пластинчатого графіту мають найбільшу теплопровідність, теплопровідність чавуну пов'язана із формою графіту, а остання - iз механічними характеристиками металу. Можна віднести форму включень графіту у чавуні у відповідність до фактора форми Ф. Кулястому графіту (ЧКГ) відповідає $\Phi=0,75 \div 1,0$ (ССГ 50-100\%; $25<\lambda<$
$35)$; чавуну з вермикулярним графітом (ЧВГ): $\Phi=$ $0,44 \div 0,74(37<\lambda<45$, ССГ 8-45\%); чавуну 3 пластинчатим графітом (ЧПГ): $\Phi=0,08 \div 0,43$ (42< $\lambda<60)$.

Рівняння вимірювань методу визначається формулою:

$$
S=\int_{\tau_{1}}^{\tau_{2}} e(\tau) d \tau,
$$

де $S$ - площа під кривою охолодження $e(\tau)$.

Вибір площі інтегрування під кривими охолодження можна виконувати двома способами: завданням довільного інтервалу часу $\Delta \tau-$ вимірюванням площі у інтервалі часу від $\tau_{0}$ до $\tau_{1}$, або завданням рівня сигналів від $e_{0}$ до $e_{1}$, i фіксації досягнення їх значень за час $\tau_{0}$ та $\tau_{1}$.

У роботах Літовки В.І. наводиться зв'язок впливу форми графіту на фізико-механічні властивості феритного і перлитного ( $\sigma-$ відносне видовження). Залежність між формою графіту та $\sigma$ і $\mathrm{a}_{\text {н }}$ практично лінійна.

За даними Літовки В. I. між формою графіту (ССГ) та фізико-механічні властивостями ( $\sigma$ відносне видовження; $\mathrm{a}_{\mathrm{H}}-$ ударна в'язкість) феритного і перлитного чавуну існує пропорційна залежність. У табл. 3 наведено результати металографічних досліджень зразків вирізаних із маточини заднього колеса автомобіля КАМАЗ.

Таблиця 3. Результати металографічних досліджень зразків вирізаних із маточини заднього колеса

\begin{tabular}{|c|c|c|c|c|c|c|c|}
\hline \multirow{3}{*}{$\begin{array}{c}\text { № } \\
\text { зразків }\end{array}$} & \multirow{3}{*}{$\begin{array}{c}\text { Ступінь } \\
\text { сфероїдизації } \\
\text { графіту, ССГ }\end{array}$} & \multicolumn{4}{|c|}{ Характеристика графіту } & \multirow{3}{*}{$\begin{array}{c}\text { Кількість } \\
\text { перлиту, } \\
П \\
\end{array}$} & \multirow{3}{*}{$\begin{array}{c}\text { Твердість, } \\
\text { НВ }\end{array}$} \\
\hline & & \multirow{2}{*}{$\begin{array}{c}3 \text { центру } \\
\text { Гф }\end{array}$} & \multicolumn{3}{|c|}{3 поверхні } & & \\
\hline & & & $\Gamma \phi$ & ШГд & ШГ & & \\
\hline 1 & 80 & $\begin{array}{l}\Gamma \phi 12,9 \\
6(p), 13(p)\end{array}$ & $\begin{array}{l}\text { Гф 9, 11, } \\
12\end{array}$ & $15-60$ & $7-8$ & $10-15$ & 174 \\
\hline 2 & 65 & $\Gamma \phi 6,12,13$ & $\begin{array}{l}\Gamma \phi 6,12, \\
12\end{array}$ & $15-25$ & $6-7$ & $4-5$ & 174 \\
\hline 3 & 55 & $\begin{array}{l}\Gamma \phi 12,13,11, \\
6,9\end{array}$ & $\begin{array}{l}\Gamma \phi 9,11, \\
12\end{array}$ & $15-60$ & $6-8$ & 10 & 172 \\
\hline 4 & 60 & $\begin{array}{l}\Gamma \phi 9,12,6, \\
11,6,9\end{array}$ & $\begin{array}{l}\Gamma \phi 9,11, \\
12\end{array}$ & $15-43$ & 8 & 10 & 166 \\
\hline 5 & 75 & $\begin{array}{l}\Gamma \phi 12,13, \\
11,9,6(\mathrm{p}) \\
\end{array}$ & $\begin{array}{l}\Gamma \phi 11,9, \\
12\end{array}$ & $15-60$ & $7-8$ & $10-15$ & 154 \\
\hline 6 & 85 & $\Gamma \phi 12,9,13$ & $\begin{array}{l}\text { Гф 12, 11, } \\
9\end{array}$ & $15-45$ & $6-8$ & $10-15$ & 172 \\
\hline 7 & 60 & $\begin{array}{l}\Gamma \phi 6,9,12, \\
13,11\end{array}$ & $\begin{array}{l}\Gamma \phi 9,11, \\
12\end{array}$ & $15-60$ & 8 & $15-20$ & 166 \\
\hline 8 & 50 & $\begin{array}{l}\Gamma \phi 6,5,11, \\
10(\mathrm{p}), 12,13\end{array}$ & Гф 6, 11, 9 & $15-60$ & 8 & $8-10$ & 170 \\
\hline 9 & $60-65$ & $\begin{array}{l}\Gamma \phi 6, \\
12(\mathrm{p}), 11(\mathrm{p})\end{array}$ & $\begin{array}{l}\Gamma \phi 9,11, \\
12,13\end{array}$ & $15-90$ & $8-9$ & $6-8$ & 177 \\
\hline 10 & $70-75$ & $\begin{array}{l}\Gamma \phi 12,13,11, \\
9,6(\mathrm{p})\end{array}$ & $\begin{array}{l}\Gamma \phi 11,9, \\
12\end{array}$ & $15-60$ & $7-8$ & $10-15$ & 154 \\
\hline 11 & 60 & $\Gamma \phi 6,12,13$ & $\begin{array}{l}\Gamma \phi 9,11, \\
12\end{array}$ & $15-60$ & $7-8$ & $6-8$ & 164 \\
\hline
\end{tabular}
автомобіля КАМАЗ 
Цифри, що позначають тип графіту: 5 - Гф 5, вермикулярний ниткоподібний; 6 вермикулярний потовщений; 9 - компактний; 10 зірковидний; 11 - кулястий розірваний; 12 кулевидний неправильної форми; 13 - кулевидний правильної форми; (р) - розірваний.

Структурна складова за ГОСТ 3443 [12]:

- графіт: пластинчатий - ПГ; вермикулярний

- ВГ; кулевидний - ШГ; компактний - КГ;

- форма включень: ПГф; ВГф; ШГф; КГф;

- розмір включень: ПГд; ШГд; КГд та цифрове позначення середнього разміру (довжина або діаметр) включень графіту (мкм);
- розподіл включень: ПГр; ВГр; ШГр;

кількість включень: ПГ; ВГ; ШГ і цифрове позначення середньої площі (\%), зайнятої графітом на мікрошліфі.

У табл. 4 наведено результати металографічних досліджень зразків із сірого чавуну СЧ 21-40. Прийняті у стандартах позначення такі: ферит - Фе 2-100\%; тип металевої матриці; оцінюється в залежності від середньої площі (\%) що займає ферит на шліфі; Фп $2000-$ середня площа трьох найбільших включень (мкм²).

Таблиця 4. Результати металографічних досліджень зразків із сірого чавуну СЧ 21-40

\begin{tabular}{|c|c|}
\hline $\begin{array}{l}\text { № } \\
\text { 3/II }\end{array}$ & Структура графіту \\
\hline 1 & Гф 1, 2, 3; Гф 2, 3, 9; Граз 60-150; Г 8-12\%; Фе 10\%; Фп 2000 \\
\hline 2 & Гф 1, 2, 4; Гф 2, 3, 9; Граз 60-150, Г 8-12\%; Фе центральна частина 2-4\%; Фе з пов. до 10\% \\
\hline 3 & Гф 1, 2, 4; Гф 2, 3, 9; Граз 60-150; Г 8-12\%; Фе 2-40\%; Фр 1; Фп 2000 \\
\hline 4 & Гф 1, 2, 4,12,13; Гр 2, 3, 9; Граз 60-120; Г 8-12\%; Фе 10\%; Фр1; Фп 2000 \\
\hline 5 & Гф 1, 2, 4; Гр 2, 3, 9; Граз 60-150; Г 8-120; Фе 4-60\%; Фр 1 не спостерігалось; Фп 2000 \\
\hline 6 & Гф 1, 2, 4; Гф 2, 3, 9, 8,9; Граз 60-120; Г 8-120; Фе в нижній частині 4-6\%;Фе 3 поверхні до 15\% \\
\hline 7 & Гф 1, 2, 5; Гр 2, 3, 8, 9; Граз 60-150; Г 8-120; Фе 2-10 10\%; Фр 1; Фп 2000 \\
\hline 8 & $\begin{array}{l}\text { Гф 1,2, 4; Гр 2, 3, 9; Граз 60-120; Г 8-12\%; Фе у центральній частині 3-10; Фе з поверхні до 15\%; Фр } \\
1 ; \text { Фп } 2000\end{array}$ \\
\hline 9 & Гф 1, 2, 4; Гф 2, 3, 9; Граз 60-150; Г 8-120; Фе 2-10\%; Фр 1; Фп 2000 \\
\hline 10 & Гф 1, 2, 4; Гр 2, 3, 9; Граз 60-120; Г 8-12\%; Фе 2-10\%; Фр 1; Фп 2000 \\
\hline
\end{tabular}

Тип матриці оцінюється за шістьма показникам (типами): ферит (Фе), перлит пластинчатий (Пт1), перлит зернистий (Пт2), троостит (Т), бейнит (Б), мартенсит (М). Кількість перлиту пластинчатого (Пт1) i фериту (Фе) оцінюється залежно від середньої площі (\%), займаної тим і іншим на шліфі; в характеристиці вказується площа перлиту: П, П96, П92, П85, П77, $\Pi 45$, П20, П6, П0, останне за умовчанням ферит (Фе) [14].

Розміри включень графіту оцінюється по довжині або 1 або по діаметру D (у мікронах) от Гразм 15 до Гразм 1000 балами.

Фосфідна евтектика оцінюються за чотирьома основними параметрами: будові (Ф1 ... Ф5); характеру розподілу (Фр1 ... Фр3); діаметру вічок сітки (Фразм250 ... Фразм1250) і середньої площі трьох найбільших включень (мкм²) Фп2000 ... Фп25000.

Поряд із словесним описом структури наводять ряд прийнятих позначень, наприклад, чавун Гф1; Г2; Гразм90; Пт1; П20; Пд1,0; Ф3; Фр1; Фразм400, ФП13000.

Теплопровідність чавунів: похибка вимірювань величини сигналу на самописці становить $\delta_{U}=3 \%$; похибка вимірювань амплітуди $\delta_{A}-5 \%$; похибка за рахунок бічних втрат теплоти у зразку $\delta_{l}=1 \%$; граничні відносні похибки у порівнянні 3 відомими методами $\delta_{\lambda}=5,2 \%$. Похибка внаслідок нещільного притискування перетворювача до дослідного зразка $\delta_{l}$ становить 2 $\%$; похибка нерівномірної у час підтримання температури перетворювача $\delta_{t}$ складає $2 \%$. Границі допустимої основної похибки вимірювання коефіцієнта теплопровідності $\lambda, \pm 5,1 \%$.

Діапазони вимірювань збільшилися: для $\lambda$, чавунів $3(30 \div 50) \mathrm{BT} /(\mathrm{м} \cdot \mathrm{K})$ до $(25 \div 55) \mathrm{BT} /(\mathrm{M} \cdot \mathrm{K})$.

Похибки вимірювання за рахунок ТФХ складових чавуну - перліту, цементиту, фериту

Оскільки теплофізичної основою методу $є$ передавання теплоти від перетворювача у масу чавуну деталі, швидкість теплообміну залежить від співвідношення $\left(\lambda_{\Pi} \cdot \rho_{\Pi} \cdot c_{\Pi} / \lambda_{ч} \cdot \rho_{ч} \cdot c_{ч}\right)^{1 / 2}$, де (п) ТФХ перетворювача, $\left({ }_{ч}\right)-$ ТФХ чавуну.

Крім теплопровідності $\lambda$ на результати вимірювання впливає теплоємність $c$ та щільність $\rho$ металевої матриці, що залежить від вмісту фериту, перлиту та графіту. Оскільки відсоток вмісту цих складових коливається у процесі виробництва в обмежених межах цих (у межах стандарту), цю похибку на заданій марці чавуну можна вважати систематичною, і такою, що не впливає суттєво на результати контролю.

У табл. 5 наведено ТФХ складових чавунів.

Прилад може бути використано для створення галузевих С3 різних марок сірого, високоміцного чавуну та чавуну з вермикулярним графітом, що застосовуються у конкретному виробництві для конкретної технології. 
Таблиця 5. ТФХ складових чавунів

\begin{tabular}{|c|c|c|c|c|}
\hline $\begin{array}{c}\text { Вид чавуну } \\
\text { та його складові }\end{array}$ & $\begin{array}{c}\text { Теплопровідність } \\
\lambda, \text { Вт/(м·К) }\end{array}$ & $\begin{array}{l}\text { Щільніст } \\
\text { ь } \\
\rho, \text { кг/м } \\
\end{array}$ & $\begin{array}{c}\text { Теплоємність } \\
\text { с, Дж/(кг·К) }\end{array}$ & Масова частка \\
\hline $\begin{array}{l}\text { Високоміцний } \\
\text { ВЧ }\end{array}$ & $\begin{array}{l}25 \div 35 \text { Изосимов } \\
{[15]}\end{array}$ & & $\begin{array}{c}540 \text { Изосимов } \\
\text { [15] }\end{array}$ & \multirow{10}{*}{$\begin{array}{l}\text { Виокоміцні чавуни (ГОСТ 7293) } \\
\text { марок ВЧ50, ВЧ60, ВЧ70, ВЧ80, } \\
\text { ВЧ100, ВЧ120 мають перлітну } \\
\text { металеву основу, } \\
\text { ВЧ35 - можуть мати ферритную; } \\
\text { ВЧ38, ВЧ42 - феритну; } \\
\text { ВЧ } 45 \text { - перлитно-феритну. } \\
\text { Степінь сфероїдизації графіту } \\
\text { (ССГ) } 50 \div 100 \% . \\
\text { Перлітні чавуни (СЧ21, СЧ32, } \\
\text { СЧ36, СЧ40). } \\
\text { Сталисті чавуни (СЧ24, СЧ28). } \\
\text { Структури: } \\
\text { П (0,8\% С) + Гр; } \\
\text { П + Ф (менше 0,8\% С) + Гр; } \\
\text { Ф + Гр } \\
\text { (весь вуглець, який є у складі } \\
\text { сплаву, наявний у формі графіту } \\
\text { пластинчатої форми. }\end{array}$} \\
\hline $\begin{array}{l}\text { ВЧ } 35 \div \text { ВЧ45 } \\
\text { ГОСТ 7293-85 } \\
{[1]}\end{array}$ & $\begin{array}{c}37,6 \div 46,0_{20}^{100} \\
{[6]}\end{array}$ & 7200 & $460 \div 502_{20}^{100}$ & \\
\hline ВЧ $60 \div$ ВЧ 80 & $33,5 \div 41,9_{20}^{100}$ & & $502 \div 523_{20}^{100}$ & \\
\hline ВЧ 100 & $29,3 \div 37,6_{20}^{100}$ & & $523 \div 565_{20}^{100}$ & \\
\hline Залізо & $(300 \mathrm{~K}) 80,4$ & 7850 & 460 & \\
\hline Графіт & $\begin{array}{l}\text { Кристалічний } \\
355,8_{0}{ }^{100} \\
\text { Природній } \\
195_{0}^{100}\end{array}$ & $\begin{array}{l}2330 \\
1800\end{array}$ & $\begin{array}{c}750 ; 795{ }_{0}^{100} \\
710\end{array}$ & \\
\hline Перліт & $50,3 \div 51,9_{0}^{100}$ & 7800 & $4860^{100}$ & \\
\hline Ферит & $72.8 \div 75,5_{0}{ }^{100}$ & 7870 & $460 \div 470_{0}^{100}$ & \\
\hline Цементіт & $49,0_{0}^{100}$ & 7660 & $615_{0}^{100}$ & \\
\hline Аустенит & $41,8_{0}{ }^{100}$ & & $5020^{100}$ & \\
\hline $\begin{array}{l}\text { Сірий } \\
\text { (СЧ) }\end{array}$ & $46 \div 54_{20}^{200}[6]$ & & 540 & \multirow{11}{*}{$\begin{array}{l}\text { Сірий чавун - вид чавуну, який } \\
\text { не містить ледебуриту, у ньому } \\
\text { весь вуглець (або частина } \\
\text { вуглецю) перебуває у вигляді } \\
\text { графиту. } \\
\text { Перлитный сірий чавун } \\
\text { Структура - перлит и } \\
\text { пластинчатий графіт. У цьому } \\
\text { чавуні } 0,7 \text { - 08\% вуглецю, і він } \\
\text { знаходиться у вигляді Ғе С, що } \\
\text { входить до складу перліту. } \\
\text { Феритно-перлитный сірий } \\
\text { чугун. } \\
\text { Структура - перлит, ферит и } \\
\text { пластинчатий графит. У цьому } \\
\text { чавуні в залежності від ступеню } \\
\text { розпаду евтектоїдного цементіту } \\
\text { у зв’язаному стані знаходиться } \\
\text { від } 0,7 \text { до 0,1\% С. } \\
\text { Феритний сірий чавун. } \\
\text { Структура - ферит та } \\
\text { пластинчатий графіт. У цьому } \\
\text { випадку весь вуглець } \\
\text { знаходиться у вигляді графіту }\end{array}$} \\
\hline $\begin{array}{l}\text { СЧ } 10-\text { СЧ18 } \\
\text { ГОСТ } 1412-85\end{array}$ & $60_{20}^{200}$ & $6800_{20}^{200}$ & $460_{20}^{200}$ & \\
\hline $\begin{array}{l}\text { СЧ } 10-\text { СЧ } 18 \\
{[2]}\end{array}$ & $46,0 \div 54,4_{20}^{100}$ & 6800 & $502 \div 544_{20}^{100}$ & \\
\hline СЧ15 & 59 & 7000 & $460_{20}^{200}$ & \\
\hline СЧ20 & 54 & 7100 & $480_{20}^{200}$ & \\
\hline СЧ25 & 50 & 7200 & $500_{20}^{200}$ & \\
\hline СЧ30 & 46 & 7300 & 525200 & \\
\hline 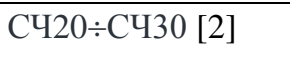 & $41,8 \div 50,2_{20}{ }^{100}$ & & $502 \div 544_{20}^{200}$ & \\
\hline СЧ35 & 42 & 7400 & $545_{20}^{200}$ & \\
\hline СЧ 35 [2] & $37,6 \div 46,0_{20}^{100}$ & & $502 \div 544_{20}^{200}$ & \\
\hline & & & & \\
\hline
\end{tabular}

\section{Висновки}

1. На основі експериментальних та теоретичних результатів викладено тепловий метод контролю форми графіту у чавуні.

2. Наведено конструкцію перетворювача теплового потоку за тепловою моделлю ізотермічного калориметра.

3. Наведено табличні значення величин теп- лопровідності різних марок чавунів відповідно до стандартів та довідкової літератури.

\section{Література}

1. Чавун з кулястим графітом для виливків. Марки: ДСТУ 3925-99. - [Чинний від 2000-07-01]. - К.: Держстандарт України, 2000. - 7 с. (Національний стандарт України). 
2. Чугун с шаровидным графитом для отливок. Марки: ГОСТ 7293-85. - [Введен в действие 0101-87]. - М.: Госстандарт СССР, 1985. - 13 с. (Межгосударственный стандарт).

3. ГСИ. Государственный первичный эталон и государственная поверочная схема для средств измерений теплопроводности твердых тел от 0,1

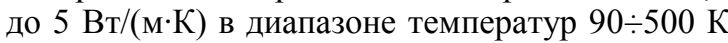
и от 5 до $20 \mathrm{BT} /($ м.К) в диапазоне температур $300 \div 1100$ К: ДСТУ ГОСТ 8.140:2009 (ГОСТ 8.140-82, IDT). - [Введен в действие с 01.02.2009]. - М.: Госстандарт СССР, 1982. 6 с. - (Межгосударственный стандарт).

4. ГСИ. Государственный первичный эталон и общесоюзная поверочная схема для средств измерения теплоёмкости твердых тел в

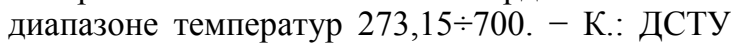
ГОСТ 8.141:2009 (ГОСТ 8.141-82, IDT). [Введен в действие с 01.02.2009]. - М.: Госстандарт СССР, $1975 . \quad$ - 7 с. (Межгосударственный стандарт).

5. Способ определения теплопроводности материалов. (Патент RU № 233466).

6. Теплофизические свойства чугуна [Електронний pecypc]: $\quad$ http://www.metizkrepej.ru/material/teplofizicheskie_svojstva_chugu na.html.

7. Захарченко Э. В. Отливки из чугуна с шаровидным и вермикулярным графитом / Э. В. Захарченко, Ю.Н. Левченко, В. Г. Горенко, П. А. Вареник. - Киев: Наукова думка, 1968. $248 \mathrm{c}$.

8. Angus H. T. Cast iron: Physical and ingeneering properties. Second Edition. - London; Boston: Butterworths, $1976 .-542 \mathrm{p}$.

9. Энциклопедия «Машиностроение». Том II-2. «Стали и чугуны» / А. И. Беляков, Н. Н. Александров, Г. Г. Мухин. - М.:
Машиностроение. ISSBN 5-217-02816-515-21701949-2, 2001. $-784 \mathrm{c}$.

10. Каленов В. П. Удельная теплоемкость серого чугунка и качество отливок // Литейное производство. - 1982. - № 9. - С. 3-4.

11. Чугун с пластинчатым графитом для отливок. Марки: ГОСТ 1412-85. - [Введено в действие 1987-01-01]. - М.: Госстандарт СССР, 1985. 5 с. (Межгосударственный стандарт).

12. Отливки из чугуна с различной формой графита. Методы определения структуры: ГОСТ 3443-87 - [Введено в действие 01.07.88]. - М.: Госстандарт СССР, 2005 (Переиздание август 2005 г. ФГУП Стандартинформ). 42 с. (Межгосударственный стандарт).

13. Салтыков С. А. Стереометрическая металлография. - М.: Металлургия, 1976. 1976. $-271 \mathrm{c}$.

14. Гильманшина Т. Р. Основы получения отливок из сплавово на основе железа. Конспект лекций / Т. Р. Гильманшина, А. И. Булгакова, В. Н. Баранов. Красноярск: 2011, Министерство образования и науки РФ Федеральное государственное автономное образовательное учреждение высшего профессионального образования «Сибирский федеральный университет», 2011 - 227 стр. [Електронний pecypc]: $\underline{\text { http://files.lib.sfu- }}$ kras.ru/ebibl/umkd/Bulgakova/u_lectures.pdf

15. Изосимов В.А. Высокопрочный чугун с вермикулярным графитом - перспективный материал для изготовления поршней двигателя Д-180 / В. А. Изосимов, В. И. Суркин, А. В. Изосимов // Вестник ЧГАУ. - 2001. - Том 35. [Електронний http://www.rsl.npp.ru/articles/castiron/article_103.html

\section{УДК 536.212:536.627}

\section{А. И. Шевченко}

Главная астрономическая обсерватория НАН Украины, г. Киев, Украина МЕТОД КОНТРОЛЯ СТЕПЕНИ СФЕРОДИЗАЦИИ ГРАФИТА В ВЫСОКОПРОЧНОМ ЧУГУНЕ

В статье приведен анализ имеющихся методов, стандартных образцов, средств измерительной техники, государственных стандартов и моделей измерений при разработке и изготовлении изделий из чугуна. Основу технологии литейного производства составляют тепловые процессы. Значительная часть всех измерений, которые выполняются в цеховых и лабораторных условиях, приходится на теплофизические измерения. Имеющиеся теплофизические методы контроля имеют недостаточно высокую чувствительность и разрешающую способность в определении технологических параметров.

Описан преобразователь и метод измерения степени сфероидизации графита в высокопрочном чугуне в промышленных условиях на автомобильном заводе. Показана связь между структурой графита в чугуне, коэффициентом теплопроводимости и измерительным сигналом.

Ключевые слова: высокопрочный чугун, преобразователь, метод контроля, коэффициент теплопроводимости чугунов.

\section{O. I. Shevchenko}

Main astronomic observatory of NAS of Ukraine, Kyiv, Ukraine

METHOD OF CONTROL THE GRAPHITE SPHERODIZATION DEGREE IN HIGHSTRENGTH CAST-IRON

The analysis of present methods is resulted in the article, state standards, facilities of measuring technique, state standards and models of measurings at creation and making of wares from cast-iron. Basis of technology of casting 
production is made by thermal processes. Considerable part of all measurings which are executed in workshop and laboratory terms is on the thermophysical measurings.

There are thermophysical methods of control have not enough a high sensitiveness and discriminability in determination of technological parameters. Described transformer and method of measuring of degree of balling in highstrength cast-iron pilot-scale at the motor-car plant. It is offered relationship between structure of graphite in castiron, by the coefficient of heat-conducting and measuring signal.

Influence of metallic matrix is marked on the results of measuring. Resulted construction of measuring transformer; results and measuring errors, examples of the controlled details of truck, which were controlled. Device it can be used for creation of a particular branch standard standards (SZ) of different brands of grey, high-strength cast-iron and cast-iron with a vermicular graphite, that used in a concrete production for concrete technology.

One over of reasons of delay of creation of standard standards is brought (SZ). It is considered that as technological control straight does not belong to the state metrology supervision, there is not a necessity to certify state SZ on enterprises during technological control. But such approach results in a volume, that when wares from these materials during the certification of machines, equipment, these wares are tested attribute to dangerous, that such which fall under a sphere state.

Simultaneously with determination of form of graphite in foundings determined the tint of macrobreaking on a wedge test: light steel - for CHSHG, mat-black - for SCH and greyish mat from by a steel-point by disseminations - for CHVG, that in accordance with statistical information on the scale of Physics and technological institute of metals alloys of the National academy of sciences of Ukraine (FTIMS NANU) answers a value from (50?60) \% (Gf5, Gf 6) to to $(70 \div 75) \%$ (Gf5, Gf6, Gf9, Gf11, 12) degrees of balling (SSG). At the same time the size of whitening cast-iron (in mm on the thickness of wedge) is thereon determined a wedge which also characterizes the effect of retrofitting at the set content of carbon and silicon in cast-iron. Next to a test on macrobreaking and whitening was periodically inundated in chill mold the thin-walled plate for determination of chemical composition of cast-iron and a large wedge was inundated for determination of mechanical properties. It is possible to take the form of including of graphite in cast-iron in accordance $\mathrm{F}$ answers with the factor of form of $\mathrm{F}$.

A spherical graphite (CHKG) is answered: 1 ) by $\mathrm{F}=0,75 \div 1,0$ (SSG $50-100 \%, 25<\lambda<35$ ); 2 ) to cast-iron with a graphite (CHVG): $\mathrm{F}=0,44 \div 0,74(37<\lambda<45$, SSG $8-45 \%) ; 3)$ to cast-iron with a graphite (CHPG): $\mathrm{F}=0,08 \div 0,43$ $(42<\lambda<60)$.

Keywords: high-strength cast-iron, transformer, control method, coefficient of heat-conducting of cast-irons.

Надійшла до редакиії 20 жовтня 2017 року

Рецензовано

(C) Шевченко О. I., 2017

02 листопада 2017 року 